\title{
PROFIL THE PHYSICAL SELF OF WELLNESS MAHASISWA S1 FAKULTAS ILMU PENDIDIKAN UNIVERSITAS NEGERI JAKARTA (Studi Deskriptif Pada Angkatan 2011-2014)
}

\author{
Ongky Aprilliyota ${ }^{1}$ \\ Dra. Atiek Sismiati ${ }^{2}$ \\ Dr. Aip Badrujaman ${ }^{3}$
}

\begin{abstract}
Abstrak
Penelitian ini bertujuan untuk mengetahui profil the physical self of wellness pada mahasiswa S1 Fakultas Ilmu Pendididkan Universitas Negeri Jakarta. Populasi dalam penelitian ini adalah 3291 mahasiswa S1 FIP UNJ dan sampelnya sebanyak 317 mahasiswa. Pengambilan sampel menggunakan teknik proportionate stratified random sampling. Metode yang digunakan adalah metode survei. Pengumpulan data dilakukan dengan memberikan kuesioner yang harus diisi oleh mahasiswa dan dilakukan analisis data dengan menggunakan pengkategorisasian. Kategorisasi dibagi menjadi lima yaitu sangat tinggi, tinggi, sedang, rendah, dan sangat rendah. Hasil Penelitian menunjukan bahwa secara keseluruhan pencapaian physical self mahasiswa S1 FIP UNJ frekuensi terbanyak berada pada kategori sedang dengan persentase 70.97\%, yang artinya secara keseluruhan mahasiswa S1 FIP UNJ cukup mampu dalam menjaga keseimbangan nutrition dan exercise secara rutin sesuai dengan kebutuhan tubuh. Implikasi dari temuan penelitian ini yaitu apabila tidak diberikan layanan informasi yang tepat akan dapat berdampak pada menurunnya prestasi akademik mahasiswa.
\end{abstract}

Kata Kunci: Physical self, nutrition, exercise

\section{Pendahuluan}

Masalah-masalah seperti stres, depresi, mencoba untuk bunuh diri dan masalah-masalah gangguan fisik menggambarkan bahwa masalah wellness pada mahasiswa menjadi hal yang penting untuk diketahui karena masalah-masalah tersebut merupakan dampak dari rendahnya wellness yang dimiliki oleh mahasiswa yang disebabkan oleh kurangnya kesadaran akan wellness.

Rendahnya wellness berdampak pada kesehat- an dan kesejahteraan mahasiswa telah diidentifikasi dalam laporan American College Health Association's National College Health Assessment (ACHANCHA) yang menunjukkan hambatan mahasiswa dalam mencapai prestasi akademis yaitu masalah emosional seperti stres, kesulitan tidur, dan depresi/kecemasan, kemudian masalah sosial seperti kepedulian terhadap teman atau keluarga dan masalah fisik seperti pilek/flu, sakit tenggorokan dan kesulitan tidur (Garcia, 2011: 5).

\footnotetext{
1 Mahasiswa Jurusan Bimbingan dan Konseling FIP UNJ,

2 Dosen Bimbingan dan Konseling FIP UNJ

3 Dosen Bimbingan dan Konseling FIP UNJ
} 
Physical self adalah proses biologis dan fisiologis yang membentuk aspek fisik pengembangan dan fungsi seseorang (Myers dan Thomas, 2008: 485). Definisi tersebut menjelaskan bahwa fisik yang sehat merupakan komponen penting untuk fungsi individu secara keseluruhan. Physical self merupakan salah satu elemen dari wellness yang memiliki peran untuk mencapai kondisi wellness secara keseluruhan. Physical self merupakan komponen tunggal yang memiliki peran sentral karena fisik yang sehat dapat berkontrubusi terhadap fungsi (tubuh, pikiran dan jiwa) individu secara maksimal (Ballentine, 2010: 23).

Penelitian yang dilakukan Trockel, Barnes, dan Egget menjelaskan bahwa ada hubungan positif antara latihan fisik dengan rata-rata nilai akademik (Ballentine, 2010: 24). Hal ini menjelaskan bahwa latihan fisik memiliki pengaruh dalam meningkatkan prestasi akademik mahasiswa.

Berdasarkan hasil studi pendahuluan yang dilakukan oleh peneliti tentang persepsi kesehatan (wellness) di Fakultas Ilmu Pendidikan Universitas Negeri Jakarta menunjukan hanya 25\% mahasiswa yang termasuk dalam kategori tinggi selebihnya mahasiswa kurang dan bahkan belum memiliki kesadaran akan physical self bagi kehidupan mereka.

Physical self merupakan hal yang penting dalam konsep wellness secara keseluruhan. Physical self adalah hal dasar yang harus dipenuhi oleh individu untuk meningkatkan elemen wellness lainnya karena kesehatan fisik yang baik akan memberikan kontribusi yang baik untuk individu dalam menjalani segala aktivitasnya. Dengan demikian physical self menjadi hal yang penting untuk diteliti karena manfaat physical self penting bagi mahasiswa dalam menjalankan segala aktivitasnya dalam perkuliahan maupun dalam menjalani hidup.

\section{Kajian Teori \\ Wellness}

Myers, Witmer dan Sweeney mendefinisikan wellness sebagai cara hidup yang berorientasi pada kesehatan yang optimal dan kesejahteraan di mana tubuh, pikiran dan jiwa yang terintegrasi oleh individu untuk hidup lebih lengkap serta dapat berinteraksi dengan dunia luar (Myers, dkk, 2000: 252). Wellness dalam pengertian ini merupakan sebuah proses aktif yang melibatkan keseluruhan dari aspek individu dalam mencapai kehidupan yang lebih utuh dan lebih baik.

\section{Indivisible Self Model of Wellness}

Indivisible Self Model of Wellness (IS-Wel) merupakan model wellness yang dikembangkan oleh Myers dan Sweeney melalui berbagai studi mengenai wellness. Model IS-Wel dapat membantu individu untuk menilai kesehatan dan mempertimbangkan perilaku serta pilihan untuk meningkatkan kesehatan individu. Dalam model IS-Wel dapat dibuktikan secara empiris, model ini dapat menyatakan dengan beberapa kepastian bahwa faktor-faktor dalam model IS-Wel saling berhubungan, yaitu perubahan disatu komponen akan memberikan kontribusi atau menyebabkan perubahan pada komponen lain.

Komponen dari model IS-Wel diukur menggunakan Inventori Lima Faktor Wellness (5F-Wel) yaitu (1) creative self adalah penggunaan kapasitas individu dalam memanfaatkan kreativitas untuk mencapai hidup yang lebih sehat dan lebih baik, (2) coping self adalah kemampuan individu yang mengatur respons individu terhadap peristiwa kehidupan dan menyediakan sarana untuk mengatasi dampak negatif dari peristiwa tersebut, (3) social self adalah dukungan sosial yang didapatkan melalui hubungan dengan orang lain dalam persahabatan dan hubungan intim (hubungan antar individu dalam konteks cinta), termasuk hubungan dengan keluarga, (4) essential self adalah kemampuan individu dalam memaknai proses yang berkaitan dengan kehidupan, dan (5) physical self adalah proses biologis dan fisiologis yang membentuk aspek fisik pengembangan dan fungsi seseorang (Myers dan Thomas, 2008: 485).

\section{Physical Self}

Physical self didefinisikan sebagai proses biologis dan fisiologis yang membentuk pengembangan aspek fisik dan fungsi seseorang. Proses biologis pada physical self adalah dengan membiasakan pola hidup yang menjaga keseimbangan nutrisi sesuai dengan kebutuhan tubuh, artinya asupan nutrisi bagi tubuh tidak berlebih dan tidak kekurangan. Sedangkan proses fisiologisnya adalah membiasakan pola hidup sehat dengan berolahraga secara rutin untuk 
menjaga kebugaran fisik.

Physical self berbeda dengan dengan physical health, karena physical self adalah proses mencapai kesehatan fisik diri yang terdiri dari proses biologis dan proses fisiologis, sedangkan physical health adalah hasil dari proses yang telah dicapai melalui kegiatan olahraga dan pola makan yang baik untuk mendapatkan kesehatan fisik.

Physical self meliputi dua komponen yaitu nutrisi (nutrition) dan olahraga (exercise). Nutrisi (nutrition) adalah memenuhi dan menjaga keseimbangan nutrisi yang sesuai dengan kebutuhan tubuh dengan mengkonsumsi makanan bergizi seimbang, menjaga berat badan normal, dan menghindari makan berlebihan. Kemudian olahraga (exercise) adalah terlibat aktif dalam aktivitas fisik yang cukup untuk menjaga kondisi fisik yang baik dan mempertahankan fleksibilitas tubuh melalui peregangan secara rutin (Myers dan Thomas, 2008: 485).

\section{Metodologi Penelitian}

Penelitian ini bertujuan untuk mengetahui profil the physical self of wellness pada mahasiswa S1 Fakultas Ilmu pendidikan Universitas Negeri Jakarta. Penelitian ini dilakukan di Fakultas Ilmu Pendidikan Universitas Negeri Jakarta dan untuk waktu penelitian dilakukan pada bulan Mei s.d Desember 2014. Metode penelitian yang digunakan dalam penelitian ini adalah metode kuantitatif dengan jenis penelitian studi deskriptif atau survei. Populasi dalam penelitian ini adalah mahasiswa Fakultas Ilmu Pendidikan angkatan 2011-2014 yang berjumlah 3291 dan sampel yang digunakan adalah 317 mahasiswa. Teknik sampling yang digunakan adalah Proportionate Stratified random sampling karena populasi anggota tidak homogen dan berstrata secara proposional.

Teknik pengumpulan data diperoleh dengan menggunakan kuesioner profil the physical self of wellness mahasiswa S1 Fakultas Ilmu Pendidikan Universitas Negeri Jakarta yang diukur de-ngan menggunakan model skala Guttman dan model skala Likert. Kuesioner tersebut terdiri dari 44 butir pernyataan meliputi aspek nutrition dan exercise. Indikator pada aspek nutrition adalah mengkonsumsi makanan bergizi seimbang, menjaga berat badan normal dan menghindari makan berlebih. Pada as- pek exercise indikatornya adalah menjaga kondisi fisik yang baik dan menjaga fleksibilitas tubuh secara rutin.

Teknik analisis data dalam penelitian ini dilakukan dengan menggunakan statistik deskriptif, yaitu statistik yang digunakan untuk menganalisis data dengan cara mendeskripsikan atau menggambarkan data yang telah terkumpul sebagaimana adanya tanpa bermaksud membuat kesimpulan yang berlaku umum.

1) Menghitung Mean Hipotetik $(\mu)$

Bagian I

$$
\begin{aligned}
\mu_{1} & =\frac{1}{2}\left(i_{\text {max }}+i_{\text {min }}\right) \sum k \\
\mu_{1} & =\text { Rerata Hipotetik } \\
i_{\text {max }} & =\text { Skor Maksimal Item } \\
\mathrm{i}_{\text {min }} & =\text { Skor Minimal Item } \\
\sum \mathrm{k} & =\text { Jumlah item }
\end{aligned}
$$

\section{Bagian II}

$$
\begin{aligned}
& \mu_{2}=\frac{1}{2}\left(i_{\text {max }}+i_{\text {min }}\right) \sum k \\
& \mu_{2}=\text { Rerata Hipotetik } \\
& \mathrm{i}_{\text {max }}=\text { Skor Maksimal Item } \\
& \dot{\mathrm{i}}_{\text {min }}=\text { Skor Minimal Item } \\
& \sum \mathrm{k}=\text { Jumlah item } \\
& \sum \mu=\mu_{1}+\mu_{2}
\end{aligned}
$$

2) Menghitung Standar Deviasi Hipotetik

Bagian I

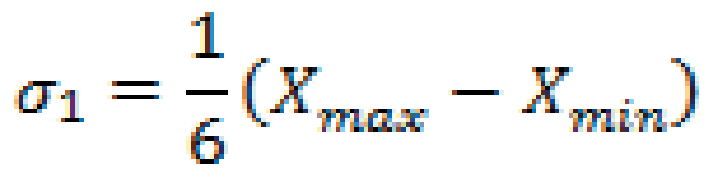

$\sigma_{1}=$ Standar deviasi hipotetik

$\mathrm{X}_{\max }=$ Skor Maksimal Subyek

$X_{\min }=$ Skor minimal Subyek 


\section{Bagian II}



$\sigma_{2}=$ Standar deviasi hipotetik

$\mathrm{X}_{\max }=$ Skor Maksimal Subyek

$\mathrm{X}_{\min }=$ Skor minimal Subyek

$$
\Sigma \sigma=\sigma_{1}+\sigma_{2}
$$

\section{Hasil Penelitian dan Pembahasan Hasil Penelitian}

Hasil penelitian menunjukan pencapaian physical self mahasiswa S1 FIP UNJ adalah 0.31\% mahasiswa pada kategori sangat tinggi, $14.19 \%$ pada kategori tinggi, $70.97 \%$ pada kategori sedang, $14.51 \%$ pada kategori rendah dan tidak ada mahasiswa pada kategori sangat rendah.

Tabel 1.1

Profil Kesehatan Diri (Physical Self) Mahasiswa FIP UNJ

\begin{tabular}{|c|c|c|c|}
\hline \multirow{2}{*}{ Kategorisasi } & \multicolumn{3}{|c|}{$\%$} \\
\cline { 2 - 4 } & Keseluruhan & Nutrition & Exercise \\
\hline Sangat Tinggi & $0.31 \%$ & $0.63 \%$ & $0.94 \%$ \\
\hline Tinggi & $14.19 \%$ & $13.24 \%$ & $16.08 \%$ \\
\hline Sedang & $70.97 \%$ & $62.77 \%$ & $64.35 \%$ \\
\hline Rendah & $14.51 \%$ & $22.71 \%$ & $18.29 \%$ \\
\hline Sangat Rendah & $0 \%$ & $0.63 \%$ & $0.31 \%$ \\
\hline
\end{tabular}

Profil physical self berdasarkan jurusan menunjukan, pada jurusan Psikologi adalah tidak ada mahasiswa pada kategori sangat tinggi, $14.81 \%$ pada kategori tinggi, $70.37 \%$ pada kategori sedang, $14.81 \%$ pada kategori rendah dan tidak ada mahasiswa yang termasuk dalam kategori sangat rendah. Pada jurusan Teknologi Pendidikan adalah 3.44\% mahasiswa pada kategori sangat tinggi, $10.34 \%$ pada kategori tinggi, $55.17 \%$ pada kategori sedang, $31.03 \%$ pada kategori rendah dan tidak ada mahasiswa yang termasuk dalam kategori sangat rendah.

Jurusan Pendidikan Luar Biasa adalah tidak ada mahasiswa pada kategori sangat tinggi, $17.24 \%$ pada kategori tinggi, $34.42 \%$ pada kategori sedang, $48.27 \%$ pada kategori rendah dan tidak ada mahasiswa yang termasuk dalam kategori sangat rendah. Pencapaian physical self jurusan Manajemen Pen- didikan adalah tidak ada mahasiswa pada kategori sangat tinggi, $13.79 \%$ pada kategori tinggi, $79.31 \%$ pada kategori sedang, dan $6.89 \%$ pada kategori rendah, dan tidak ada mahasiswa pada kategori sangat rendah.

Hasil penelitian menunjukan pencapaian physical self pada jurusan Pendidikan Luar Sekolah adalah tidak ada mahasiswa pada kategori sangat tinggi, $6.45 \%$ pada kategori tinggi, $77.41 \%$ pada kategori sedang, dan $16.12 \%$ mahasiswa pada kategori rendah, dan tidak ada mahasiswa dalam kategori sangat rendah. Profil secara keseluruhan jurusan Pendidikan Anak Usia Dini adalah tidak ada mahasiswa pada kategori sangat tinggi, $16.66 \%$ pada kategori tinggi, $83.33 \%$ pada kategori sedang, dan tidak ada mahasiswa pada kategori rendah maupun dalam kategori sangat rendah.

Hasil pencapaian jurusan Bimbingan dan Konseling adalah tidak ada mahasiswa pada kategori sangat tinggi, $16.66 \%$ pada kategori tinggi, $80 \%$ pada kategori sedang, dan 3.33\% mahasiswa pada kategori rendah dan tidak ada mahasiswa dalam kategori sangat rendah. Pada jurusan Pendidikan Guru Sekolah Dasar adalah tidak ada mahasiswa pada kategori sangat tinggi, $15.18 \%$ pada kategori tinggi, $75.94 \%$ pada kategori sedang, dan $8.86 \%$ mahasiswa pada kategori rendah dan tidak ada mahasiswa dalam kategori sangat rendah.

Tabel 1.2

Profil Kesehatan Diri (Physical Self) Mahasiswa FIP UNJ Berdasarkan Jurusan

\begin{tabular}{|c|c|c|c|c|c|}
\hline \multirow{2}{*}{ Jurusan } & \multicolumn{5}{|c|}{$\%$ Keseluruhan } \\
\cline { 2 - 6 } & ST & T & S & R & SR \\
\hline P & $0 \%$ & $14.81 \%$ & $70.37 \%$ & $14.81 \%$ & $0 \%$ \\
\hline TP & $3.44 \%$ & $10.34 \%$ & $55.17 \%$ & $31.03 \%$ & $0 \%$ \\
\hline PLB & $0 \%$ & $17.24 \%$ & $34.48 \%$ & $48.27 \%$ & $0 \%$ \\
\hline MP & $0 \%$ & $13.79 \%$ & $79.31 \%$ & $6.89 \%$ & $0 \%$ \\
\hline PLS & $0 \%$ & $6.45 \%$ & $77.41 \%$ & $16.12 \%$ & $0 \%$ \\
\hline PAUD & $0 \%$ & $16.66 \%$ & $83.33 \%$ & $0 \%$ & $0 \%$ \\
\hline BK & $0 \%$ & $16.66 \%$ & $80.00 \%$ & $3.33 \%$ & $0 \%$ \\
\hline PGSD & $0 \%$ & $15.18 \%$ & $75.94 \%$ & $8.86 \%$ & $0 \%$ \\
\hline
\end{tabular}

Berdasarkan jenis kelamin hasil penelitian menunjukan pencapaian physical self mahasiswa S1 laki-laki FIP UNJ adalah $1.35 \%$ pada kategori sangat tinggi, $12.16 \%$ pada kategori tinggi, $71.62 \%$ pada kategori sedang, $14.86 \%$ pada kategori rendah dan tidak ada mahasiswa pada kategori sangat rendah. 
Sedangkan mahasiswa perempuan adalah tidak ada mahasiswa pada kategori sangat tinggi, $14.81 \%$ pada kategori tinggi, $70.78 \%$ pada kategori sedang, $14.40 \%$ pada kategori rendah dan tidak ada mahasiswa pada kategori sangat rendah.

Tabel 1.3

Profil kesehatan diri (physical self) mahasiswa S1 FIP UNJ berdasarkan jenis kelamin

\begin{tabular}{|c|c|c|c|c|c|c|}
\hline \multirow{2}{*}{$\begin{array}{c}\text { Katego- } \\
\text { risasi }\end{array}$} & \multicolumn{5}{|c|}{$\%$} \\
\cline { 2 - 7 } & \multicolumn{5}{|c|}{ Laki-laki } & \multicolumn{3}{c|}{ Perempuan } \\
\cline { 2 - 7 } & Keseluruhan & Nutrition & Exercise & Keseluruhan & Nutrition & Exercise \\
\hline ST & $1.35 \%$ & $1.35 \%$ & $1.35 \%$ & $0 \%$ & $0.41 \%$ & $0.82 \%$ \\
\hline T & $12.16 \%$ & $12.16 \%$ & $21.62 \%$ & $14.81 \%$ & $13.58 \%$ & $1440 \%$ \\
\hline S & $71.62 \%$ & $60.81 \%$ & $63.51 \%$ & $70.78 \%$ & $63.37 \%$ & $64.60 \%$ \\
\hline R & $14.86 \%$ & $25.67 \%$ & $13.51 \%$ & $14.40 \%$ & $21.81 \%$ & $19.75 \%$ \\
\hline SR & $0 \%$ & $0 \%$ & $0 \%$ & $0 \%$ & $0.82 \%$ & $0.41 \%$ \\
\hline
\end{tabular}

Hasil penelitian menunjukan pencapaian physical self mahasiswa S1 berdasarkan angkatan yaitu pada angkatan 2011 FIP UNJ adalah 1.14\% mahasiswa pada kategori sangat tinggi, $17.24 \%$ pada kategori tinggi, $73.56 \%$ pada kategori sedang, $8.04 \%$ pada kategori rendah dan tidak ada mahasiswa pada kategori sangat rendah. Angkatan 2012 FIP UNJ adalah tidak ada mahasiswa pada kategori sangat tinggi, $8.69 \%$ pada kategori tinggi, $71.73 \%$ pada kategori sedang, $19.56 \%$ pada kategori rendah dan tidak ada mahasiswa pada kategori sangat rendah.

Hasil penelitian menunjukan pencapaian physical self mahasiswa S1 angkatan 2013 FIP UNJ adalah tidak ada mahasiswa pada kategori sangat tinggi, $15.49 \%$ pada kategori tinggi, $69.01 \%$ pada kategori sedang, $15.49 \%$ pada kategori rendah dan tidak ada mahasiswa pada kategori sangat rendah. Angkatan 2014 FIP UNJ adalah tidak ada mahasiswa pada kategori sangat tinggi, $16.41 \%$ pada kategori tinggi, $68.65 \%$ pada kategori sedang, $14.92 \%$ pada kategori rendah dan tidak ada mahasiswa pada kategori sangat rendah.

Tabel 1.4

Profil kesehatan diri (physical self) mahasiswa S1 FIP UNJ berdasarkan angkatan

\begin{tabular}{|c|c|c|c|c|}
\hline \multirow{2}{*}{ Kategorisasi } & \multicolumn{4}{|c|}{ A } \\
\cline { 2 - 5 } & $\mathbf{4}$ & $\mathbf{4}$ \\
\cline { 2 - 5 } & $\mathbf{2 0 1 1}$ & $\mathbf{2 0 1 2}$ & $\mathbf{2 0 1 3}$ & $\mathbf{2 0 1 4}$ \\
\hline ST & $1.14 \%$ & $0 \%$ & $0 \%$ & $0 \%$ \\
\hline T & $17.24 \%$ & $8.69 \%$ & $15.49 \%$ & $16.41 \%$ \\
\hline S & $73.56 \%$ & $71.73 \%$ & $69.01 \%$ & $68.65 \%$ \\
\hline R & $8.04 \%$ & $19.56 \%$ & $15.49 \%$ & $14.92 \%$ \\
\hline SR & $0 \%$ & $0 \%$ & $0 \%$ & $0 \%$ \\
\hline
\end{tabular}

\section{Pembahasan}

Hasil penelitian menunjukkan bahwa secara keseluruhan profil kesehatan diri (physical self) mahasiswa S1 Fakultas Ilmu Pendidikan Universitas Negeri Jakarta rata-rata berada pada kategorisasi sedang. yang artinya mahasiswa cukup mampu dalam menjaga keseimbangan nutrisi dan aktivitas fisik secara rutin.

Data pencapaian physical self berdasarkan jurusan menunjukan bahwa persentase tiga tertinggi adalah jurusan Pendidikan Anak Usia Dini, Bimbingan dan Konseling dan Manajemen Pendidikan. Pada jurusan Pendidikan Anak Usia Dini dan Bimbingan dan Konseling terdapat matakuliah yang berhubungan dengan nutrisi dan aktivitas fisik. Pada Jurusan Pendidikan Anak Usia Dini yaitu pada matakuliah kesehatan anak usia dini, gizi anak usia dini dan antropobiologi, sedangkan pada jurusan Bimbingan dan Konseling adalah matakuliah kesehatan mental yang mempelajari tentang wellness dan wellbeing. Pada jurusan Manajemen Pendidikan kemampuan mahasiswa dalam melakukan manajemen dan informasi yang dimiliki mengenai kesehatan fisik kemungkinan menjadi faktor pencapaian physical self mahasiswa jurusan Manajemen Pendidikan.

Pencapaian physical self berdasarkan jurusan yang terendah adalah Jurusan Pendidikan Luar Biasa, Teknologi Pendidikan dan Psikologi. Rendahnya pencapaian jurusan-jurusan tersebut kemungkinan disebabkan oleh kurangnya informasi yang dimiliki oleh mahasiswa atau kurangnya informasi yang diberikan oleh jurusan terkait dengan physical self.

Data hasil pencapaian physical self berdasarkan jenis kelamin menunjukan bahwa persentase lakilaki lebih banyak daripada perempuan. Hasil penelitian tersebut sesuai dengan hasil penelitian yang dilakukan oleh Myers dan Mobley yang menjelaskan bahwa skor laki-laki lebih tinggi dibandingkan perempuan dalam aspek physical self (Myers, dkk, 2003: 264).

Data hasil penelitian physical self berdasarkan angkatan menunjukan bahwa angkatan 2011 adalah angkatan yang mendapatkan persentase tertinggi dan angkatan 2014 adalah yang terendah. Data hasil penelitian tersebut didukung oleh penelitian yang 
dilakukan oleh oleh Roach, melalui survei pada 204 mahasiswa S2 konseling, menunjukan pengaruh lamanya program pelatihan wellness pada tingkatan wellness. Artinya, semakin lama seorang mahasiswa mempelajari wellness akan memiliki tingkatan wellness yang lebih tinggi (Myers, Thomas, 2008: 488).

\section{Simpulan dan Saran}

Berdasarkan hasil penelitiandapat disimpulkan secara keseluruhan profil kesehatan diri (physical self) mahasiswa S1 Fakultas Ilmu Pendidikan Universitas Negeri Jakarta rata-rata berada pada kategorisasi sedang. yang artinya mahasiswa cukup mampu dalam menjaga keseimbangan nutrisi dan aktivitas fisik secara rutin.

Data pencapaian physical self berdasarkan jurusan menunjukan bahwa persentase tiga tertinggi adalah jurusan Pendidikan Anak Usia Dini, Bimbingan dan Konseling dan Manajemen Pendidikan. Sedangkan pencapaian terendah adalah Jurusan Pendidikan Luar Biasa, Teknologi Pendidikan dan Psikologi.

Berdasarkan jenis kelamin data hasil pencapaian physical self menunjukan bahwa persentase laki-laki lebih banyak daripada perempuan. Kemudian data hasil penelitian physical self berdasarkan angkatan menunjukan bahwa Angkatan 2011 adalah angkatan yang mendapatkan persentase tertinggi dan Angkatan 2014 adalah yang terendah.

Saran yang dapat menjadi pertimbangan berdasarkan hasil penelitian ini adalah:
Saran untuk Unit Layanan Bimbingan dan Konseling, temuan ini dapat dijadikan informasi atau data untuk mempertimbangkan layanan konseling yang tepat guna untuk meningkatkan physical self mahasiswa. Kemudian saran untuk Fakultas Ilmu Pendidikan, temuan ini dapat dijadikan sebagai ba-han pertimbangan untuk menyediakan fasilitasfasilitas olahraga dan penyediaan kantin guna meningkatkan physical self mahasiswa. Saran untuk jurusan di Fakultas Ilmu Pendidikan, temuan ini dapat dijadikan pertimbangan untuk memberikan informasi guna meningkatkan physical self mahasiswa.

\section{Daftar Pustaka}

Ballentine Howard Monroe, et al, "The Relationship Between Wellness and Academic Success in First-year College Students" Dissertation, 20 April 2010, The Faculty of Virginia Polytechnic Institute and State University, Virginia.

Garcia Kristina Marie, "The Impact of College Students" Life Experiences on The Various Dimensions of Wellness: A Qualitative Study", Dissertation, May 2011

Myers, J. E, Mobley, K., \& Booth, C. S, "Wellness of Counseling student : Practicing what we preach" Counselor Education \& Supervision, 2003.

Myers, Jane E, Thomas J Sweeney, and J. Melvin Witmer, "The Wheel of Wellness Counseling for Wellness : A Holistic Model for Treatment Planning", Journal of Counseling \& Development, Vol. 78, Summer 2000.

Myers, Jane E and Thomas J Sweeney, "Wellness Counseling: The Evidence Base for Practice" Journal of Counseling \& Development, Fall 2008, Volume 86. 